\title{
Review of the medicinal potential of the Flora of Embu-Verde Environmental
}

\section{Preservation Area}

\author{
Revisão sobre o potencial medicinal da Flora da Area de Preservação Ambiental Embu-Verde \\ Revisión sobre el potencial medicinal de la Flora del Área de Preservación Ambiental Embu-Verde
}

Received: 04/20/2021 | Reviewed: 04/27/2021 | Accept: 05/04/2021 | Published: 05/19/2021

\author{
Josiane Félix Sousa \\ https://orcid.org/0000-0003-3343-5126 \\ Anhanguera University of São Paulo, Brazil \\ E-mail: josyfelixx1@gmail.com \\ Julia Alejandra Pezuk \\ https://orcid.org/0000-0001-5412-6619 \\ Anhanguera University of São Paulo, Brazil \\ E-mail: julia.pezuk@hotmail.com \\ Simone dos Santos Grecco \\ https://orcid.org/0000-0003-0716-0368 \\ Triplet Biotechnology Solutions, Brazil \\ E-mail: simonegrecco@tripletbs.com
}

\begin{abstract}
The Atlantic Forest Biome is essential for $72 \%$ of the Brazilian population, but only a small part of the population has knowledge and values this environmental heritage. This biome is under constant threat; thus, strategies and actions are needed for its preservation and conservation. The Embu-Verde Environmental Preservation Area (EPA) concentrates a big part of the remaining biodiversity of the Atlantic Forest, and because it is close to the largest urban center in the country, it is increasingly threatened. The use of plants as a medicinal tool has been explored since the beginning of mankind. In fact, many of the compounds used in the health area derive from the flora. In this context, this study aimed to identify the medicinal potential of the EPA Embu-Verde flora, from the perspective that it is necessary to know to be able to preserve. Based on previous studies registering the biodiversity of EPA Embu-Verde, all the species of flora listed were investigated to identify its medicinal potential. We show here that of the 202 native species identified in the EPA Embu-Verde, there are 35 species of 23 botanical families that presented medicinal potential. The Myrtaceae family was the most cited, and its anti-inflammatory potential was the most prominent, moreover, several other uses were reported for the remaining flora. The medicinal potential of the flora of EPA Embu-Verde is still underestimated, therefore the recognition of medicinal species by the population is important. The preservation of the flora is essential to guarantee the possibility of future bioprospecting studies that will investigate the therapeutic potential of the still unknown medicinal species.
\end{abstract}

Keywords: Biodiversity; Atlantic forest; Medicinal plants; Environmental preservation; Environmental education.

\section{Resumo}

O Bioma Mata Atlântica é essencial para $72 \%$ da população do Brasil, porém apenas uma pequena parte da população possui conhecimento e valoriza esse patrimônio ambiental. Este bioma está em constante ameaça, sendo necessárias estratégias e ações para sua preservação e conservação. A Area de Preservação Ambiental (APA) Embu-Verde concentra grande parte da biodiversidade remanescente da Mata Atlântica, e por estar próxima ao maior centro urbano do país, está cada vez mais ameaçada. O uso de plantas como ferramenta medicinal tem sido explorado desde o começo da humanidade. De fato, muitos dos compostos usando na área da saúde derivam da flora. Nesse contexto, este estudo buscou identificar o potencial medicinal da flora da APA Embu-Verde, sob a perspectiva de que é preciso conhecer para preservar. Com base em estudos anteriores que registram a biodiversidade da APA Embu-Verde, todas as espécies da flora listadas foram investigadas para identificar o potencial medicinal. Mostramos aqui que das 202 espécies nativas identificadas na APA Embu-Verde, há 35 espécies de 23 famílias botânicas que apresentaram potencial medicinal. A família da Myrtaceae foi a mais citada, sendo seu potencial anti-inflamatório o mais destacado, ainda diversos usos foram relatados para a flora remanescente. Embora o potencial medicinal da flora da APA EmbuVerde ainda seja subestimado, é importante o reconhecimento dessas espécies medicinais pela população. A preservação da flora é essencial para garantir a possibilidade de realização de futuros estudos de bioprospecção para investigar o potencial terapêutico das espécies medicinais ainda desconhecidas.

Palavras-chave: Biodiversidade; Mata atlântica; Plantas medicinais; Preservação ambiental; Educação ambiental. 


\section{Resumen}

El Bioma de la Mata Atlántica es esencial para el $72 \%$ de la población brasilera, pero solo una pequeña parte de la población conoce y valora este patrimonio ambiental. Este bioma está en constante amenaza, siendo necesarias estrategias y acciones para su preservación y conservación. El Área de Preservación Ambiental (APA) Embu-Verde concentra gran parte de la biodiversidad remanente de la Mata Atlántica, y por estar cerca del mayor centro urbano del país, está cada vez más amenazada. El uso de plantas como herramienta medicinal ha sido explorado desde el comienzo de la humanidad. De hecho, muchos de los compuestos utilizados en salud derivan de la flora. En este contexto, este estudio busca identificar el potencial medicinal de la flora de la APA Embu-Verde, bajo la perspectiva de que es necesario saber para poder preservar. Con base en estudios previos que registran la biodiversidad de la APA Embu-Verde, todas las especies de flora citadas han sido investigadas de acuerdo con su potencial medicinal. Mostramos aquí que de las 202 especies nativas identificadas en la APA Embu-Verde, hay 35 especies que pertenecen a 23 familias botánicas que presentan potencial medicinal. La familia Myrtaceae es la más citada, siendo su potencial antiinflamatorio el más destacado, además de otros usos para la flora restante. El potencial medicinal de la flora de EPA Embu-Verde aún está subestimado, por eso es importante el reconocimiento de las especies medicinales por parte de la población. La preservación de la flora es fundamental para garantizar la posibilidad de futuros estudios de bioprospección que permitan investigar el potencial terapéutico de las especies medicinales aún desconocidas.

Palabras clave: Biodiversidad; Bosque atlántico; Plantas medicinales; Preservación del medio ambiente; Educación ambiental.

\section{Introduction}

The Atlantic Forest (AF) is one of the most important and threatened biomes in the Brazilian territory. Its most striking characteristics are the high precipitation index, humidity, and average temperature, which ranges from 20 to $25^{\circ} \mathrm{C}$, which contribute to a high biodiversity index (Dolenc, Pelosoni \& Fabrinni, 2013). AF is one of the main sites that preserve the largest global biodiversity. It has a flora composed of about 25 thousand species, the most prevalent being the bryophytes, climbing plants and orchids, being $50 \%$ of them endemic. Currently, AF is protected by legislation and it is a National Heritage Site by the 1988 Constitution, and is recognized by UNESCO as a Biosphere reserve, and by the UN as a World Heritage Site. Despite of its potential this biome is in constant threat of extinction (Colombo \& Joly, 2010). AF occupies almost the entire Brazilian coast, which at the time of colonization of Brazil represented more than 1.3 million $\mathrm{km}^{2}$, covering about $15 \%$ of the national territory. However, human occupation has caused this biome to be more devastated every year, with only around $12 \%$ of the original area remaining today. The lack of supervision by the competent authorities and impunity favors the continuation of deforestation. Additionally, the general absence of environmental responsibility and awareness facilitate the irrational use of resources leading to irreversible impacts on this biome (SOS Mata Atlântica, 2020).

AF is estimated to be a source of life for more than 110 million people, mainly due to its water resources, such as the springs and rivers that supply part of the country's population. The preservation of this biome is essential for maintaining the climate and precipitation levels, as well as for protecting the slopes of Serra do Mar and the Fauna and Flora that exist there. Although at least $72 \%$ of the Brazilian population enjoys the advantages of this biome, there is no awareness of the value of this environmental heritage by a large portion of the population. AF preservation is necessary not only for the climatic or water advantages, but because this biome is home for many species representing a huge genetic diversity not yet fully known or exploited. The flora species present in AF have a vast potential for medicinal use, therefore the conservation of this biome can impact on advances in biotechnological research, as well as essential economic activities such as fishing, energy generation and tourism and leisure activities, all with a focus on sustainability (SOS Mata Atlântica, 2020).

One of the strategies that seek to promote environmental preservation is the creation of laws, which delimit areas to ensure the conservation of biodiversity present in nature and at the same time ensure access to the environmental goods and services available in these spaces. The first Brazilian law for environmental preservation dates from 1981 (Law number 6.902, 1981), and since then several laws have been approved seeking to regulate actions that promotes the sustainable use of resources to guarantee Brazilian biodiversity preservation. However, it is known that the existence of laws is not enough to ensures that there will be no impact on the environment. Indeed, environmental education in schools is also a necessary 
strategy, to facilitate the changes needed to understand a better way to consume products that use raw materials from environmental resources are consumed. Environmental education aims to implement awareness and responsibility, both for society and organizations, to promote initiatives to rethink the forms of products production, to reduce the degradation and negative environmental impacts such as those from the waste.

Public authorities of the Federal, State and Municipal spheres need to be more active and punctual on the supervision and elaboration of public policies for environmental resources preservation, to be able to efficiently inhibit and contain the negative impacts caused by companies and civil society. Once that preserving environmental resources is essential for the survival of human, animal, and plant species. AF biome is constantly under threat, so strategies and actions for its preservation and conservation are urgent. The sustainable use of natural resources establishes criteria for using them in a rational way and to maintain their continuity without causing impacts for the current and the next generations (Almeida, 2014).

The city "Estância Turística de Embu das Artes" located in the Metropolitan Region of São Paulo (MRSP), about 27 km away from the central landmark of the capital of the State of São Paulo, Brazil, and covers much of the original area of AF. According to data from the City hall of Embu das Artes, the city's main economic activities are industry, agriculture, tourism, and commerce (Embu das Artes, 2020). As its name suggests, the greatest recognition and attraction of the municipality is tourism, especially geared to the arts, for its architecture and commerce of antiques and furniture. The city is located in the morphoclimatic scope of AF, where due to the predominance of humidity in the air masses, a type of dense and pleasant vegetation originated. In fact, the municipality is in a transitional zone of flora, in these conditions both coast and mountain species as well as interior species can be found. Within the AF vegetation that predominates in the city, the formation of secondary forests is highlighted, which are nothing more than evidence of the recompositing process (Mota, 2018). Currently there are still preserved stretches of AF in 3\% of its territory. These preserved areas are also found in other municipalities nearby, forming the so-called Green Belt of RMSP, and are part of the Biosphere reserve, being recognized by UNESCO as a heritage site (SOS Mata Atlântica, 2020).

Knowing the wealthiness of biodiversity present in this region, in December 2008 the Embu-Verde Environmental Protection Area (EPA) was created (complementary law n 108), which covers 16 of the $72 \mathrm{~km}^{2}$ of the so-called Green Belt. Inserted in AF Biome, EPA Embu-Verde has a wide range of environmental services, with some of its little explored potential. The responsible, conscious, and participatory use of these resources can contribute to the well-being and quality of life of the region's population. Information on the importance of these resources and their use is fundamental to recognize and value the potential of this biodiversity, benefiting, without causing degradation and negative impacts, focusing on the AF preservation and conservation. Managing all these resources is challenging and passes through ethical, cultural, social, and economic issues, and public policies are needed to build environmental awareness for the citizen education. EPA Embu-Verde is part of the world heritage of biodiversity and was created with a view to its conservation and preservation, seeking the sustainable use of resources for the benefit of the Embu environment and population (Dolenc, et al., 2013).

Since its creation, in December 2008, no studies have been carried out to investigate the medicinal potential to the existing Flora in Embu-Verde EPA. In this context, the objective of this study was to discuss and highlight the important points that led to the creation of EPA Embu-Verde and to identify the medicinal potential of the plants present in EPA Embu-Verde. Thus, this research seeks to incentive health promotion of the population aiming the sustainability and preservation of the AF remaining area, whose biodiversity is indispensable for the maintenance and continuity of human life, contributing to the environmental preservation.

\section{Methodology}

This is a qualitative research, relating to a master's project, and can be characterized as theoretical study focused on 
the search and literature revision classify as a case study. According to Yin (2015) a case study investigates a topic following a set of pre-specified procedures. This study was carried out to produce information that helps promote the sustainable use of biodiversity resources in the health area, favoring environmental balance, quality of life and health based on knowledge and access to the use of medicinal plants.

In order to discuss the relevance of environmental preservation, the legislations that envisage and create areas of environmental protection in the Brazilian territory were explored. The Legal Framework and the creation of Embu-Verde EPA are described through the analysis of the objectives and guidelines contained in complementary Law number 108, which contains the criteria for the use and management of Embu-Verde EPA. Among the guidelines and objectives proposed in Embu-Verde EPA Law, it was sought to emphasize on the resources management and utility focusing on the benefit of the population by the promotion of life's quality of life.

To understand the medicinal potential of Embu-Verde EPA's plants, it was used the study carried out by Instituto Florestal (Secretaria do Meio Ambiente, 2006), in which the flora's species are identified and listed. Initially, the medicinal potential of each plant mentioned was search in the in the National List of Medicine plants of interest to the National Health System - Renisus (2020). Moreover, the book published by Lorenzi and Matos describing plants with medicinal potential in Brazil (Secretaria do Meio Ambiente, 2006) was also used to identify plant with therapeutic used. In addition, species that were not identified in the Renisus or in the book of Lorenzi and Matos were verified through an exploratory literary review that seek to identify medical use description for plant in databases such as Pubmed. This search was carried out using the plants' scientific name as a descriptor. The articles referred to each species were analyzed in full to verify whether they included indication of medicinal use. All publication that did not included therapeutic uses for the species were discard.

\section{Results and Discussion}

\section{Legal framework for the Embu-Verde EPA creation}

Embu-Verde EPA, which is part of the green belt of the metropolitan region of São Paulo, was created by complementary Law number 108 in December 2008 (2008), that was consolidated with several changes until June/2019. Its creation was based on the prerogative conferred by UNESCO, as an Environmental Heritage, for being a Biosphere reserve and having AF tracts. In its first article, the law lays down the criteria for the EPA use and management, and the EPA importance for the city is evidence next. Article number 4 describe the objectives of EPA creation, and among them it is important to highlighted:

I - To promote the improvement of the population quality of life.

II - To promote the use of nature conservation principles and practices in the development process.

III - To promote the sustainable use of natural resources; (...)

$\mathrm{X}$ - To expand the municipality's economic self-support base, generating employment and income for the local population.

XIII - the promotion of public policies through a permanent process of decentralized democratic management of the city and popular participation.

XIV - To promote formal and non-formal environmental education.

It is noted that the criteria and objectives mentioned in the legislation that created the Embu-Verde EPA are given the conditions for the use of environmental resources based on the sustainability requirements. In fact, the municipality has an environment conducive to the promotion and construction of knowledge about medicinal plants, allowing its dissemination, which is probably lost along the trajectory of the city historical formation. The space defined as EPA was thus designated due 
the greatest biodiversity of fauna and flora, listed as endangered, and as it is a source of environmental services available to the population of the city and state of São Paulo (Dolenc, et al., 2013).

Since its creation, many studies have been carried out on the potential of existing resources in Embu-Verde EPA, but little or almost nothing exists about the study and knowledge of flora with medicinal potential present there. In 2008, the municipality of Embu, with FEHIDRO (Fundo Estadual de Recursos Hidricos) financing with the support of SEAE (Sociedade Ecológica Amiga de Embu), elaborated the socio-environmental Atlas of Embu das Artes, in which the city history was recorded, and including the description of socioeconomic profile, types of fauna and flora in Embu-Verde EPA, water resources, as well as the river basins to which it belongs (Melo \& Franco, 2008).

Moreover, the SEAE, in 2013, carried out a survey of the flora and fauna of Embu-Verde EPA, with the focus being to disseminate scientifically data on all the biodiversity found there (Dolenc, et al., 2013). At the same time, the study checks the fauna transit in the forest, along the corridors used by the animals and the connection among the border neighborhoods, essential for the biodiversity maintenance. It is known that in the management and sustainable use of EPA resources, there must be a balance among economic development, preservation, and conservation. To this end, it is necessary to consider the social and cultural issues of the populations living in the region, establishing actions and criteria that comply with EPA integration, for the whole municipality, since it is everybody's heritage. It is important that the benefits of this interaction are accessible and known to all Embu citizens. Thus, SEAE identified that since EPA is owned by the municipality, the possibility of valuing this property is broad and significant and may be import for the:

- Improvement of the population quality of life.

- Scientific research, increasing knowledge about the area and contributing to the understanding of the important relations between the various existing ecosystems and their questioning with the environmental balance and the population health.

-Strengthen the cultural and social identity of communities through participatory planning and EPA collaborative management.

- Preservation and protection of the ecosystems and their ecological processes, guaranteeing the sustainability and preservation of biodiversity.

SEAE study makes it clear that the environmental and social benefits for the population of the municipality are many, thus efforts must be coordinated to reach everybody, through actions that promote knowledge about the EPA and its resources (Dolenc, et al., 2013). It is necessary to encourage research and study of the biodiversity present, leading to collective and planned participation, giving cultural and social visibility, generating identity bonds in the community, culminating in the understanding of the various environmental relations and their equilibrium processes, which result in protection, preservation, sustainable use, and local population quality of life improvement. Initiatives that disseminate EPA helped to promote its conservation and preservation.

Embu-Verde EPA has a wide range of genetic diversity in its flora and fauna, the sustainability of its resources is fundamental not only for biodiversity but also for the interactions among traditional cultures, which have resulted in the secular human knowledge of this ecosystem. Its preservation impact on cultural experiences, leaving a legacy of great appreciation, increasing its productivity, and emphasizing the sustainable use and occupation of the current environment. Actions aimed at preservation and conservation should be guided by the relationships of total harmony between the native populations and the environment. Embu-Verde EPA, as part of the Biosphere reserve, can be explored to promote environmental education and can fostering specialized labor formation. Despite scientists, professionals from other areas and the population and visitors can cooperate to obtain information and discoveries, contributing to the elaboration of strategies for sustainability to reduce 
environmental negative impacts of resources uses.

The knowledge is the key to incentive the preservation, and to promote rational and sustainable use of Embu-Verde EPA uses, seeking an equitable access to its benefits, aligning the traditional to scientific, in the search for solutions to both environmental and social issues. It is essential that all efforts are directed toward the preservation, especially from the State, to bring information, knowledge, and education to safeguard all this biodiversity. The actions and strategies feasibility are necessary for the study and discovery of the utility of biodiversity, without the negative impacts of its used caused during years of unordered and predatory exploitation. Therefore, constant monitoring and evaluation are necessary throughout the process (Ministério do Meio Ambiente, 2017).

\section{Medical Potential of Embu-Verde EPA}

The Instituto Florestal de São Paulo conducted and published a study entitled Evaluation of Embu Forest Remnants, which identifies the environmental resources available, such as water resources, fauna, flora and all its potential for the development of Ecological Tourism in the city (Secretaria do Meio Ambiente, 2006). According to this survey, 202 native species were identified in the remaining AF fragments, classified, and distributed in 152 genera and 60 families, comprising approximately 58-67\% of the region's original species. After the search of medicinal potential of those plant it was possible to observe that 35 species of EPA flora presented evidence of therapeutic uses (table 1). Several plants have been described to treat symptoms associated with common pathological conditions such as fever, inflammation, and pain, and some with more specific indications such as antiophidic use, ulcers treatments and microbial infections. The parts of the plants to be used should be considered, since the indication varies according to the same, which can be explained by the different chemical characteristics found in leaves, roots, stems, flowers, and fruits of the same plant.

Table 1. Medicinal plants of Embu-Verde EPA. Indication of medicinal use according to the name of the species and botanical family.

\begin{tabular}{|c|c|c|c|}
\hline $\begin{array}{l}\text { Botanical } \\
\text { family }\end{array}$ & Plant species & Medicinal use & References \\
\hline Acanthaceae & Justicia carnea & antianemia and blood tonic & $\begin{array}{l}\text { Anthonia Ikechukwu, Uzoma, and } \\
\text { Sunday, } 2019 .\end{array}$ \\
\hline \multirow{3}{*}{ Anacardiaceae } & $\begin{array}{l}\text { Lithraea } \\
\text { molleoides }\end{array}$ & arthritis; digestive; diuretic and respiratory diseases & $\begin{array}{l}\text { Kott, Barbini, Cruañes, Muñoz, } \\
\text { Vivot, Cruañes, Martino, Ferraro, } \\
\text { Cavallaro, and Campos } 1998 .\end{array}$ \\
\hline & $\begin{array}{l}\text { Schinus } \\
\text { terebinthifolius }\end{array}$ & $\begin{array}{l}\text { anti-inflammatory; analgesic; purification; gastroduodenal } \\
\text { disorders; skin ulcers; STD; urinary tract; antipyretic and } \\
\text { uterine inflammation; }\end{array}$ & $\begin{array}{l}\text { Carvalho, Melo, Aragão, Raffin, } \\
\text { and Moura, } 2013 .\end{array}$ \\
\hline & $\begin{array}{l}\text { Tapirira } \\
\text { guianensis }\end{array}$ & infected external wounds; canker sores; malaria; diarrhea; & $\begin{array}{l}\text { Roumy, Fabre, Portet, Bourdy, } \\
\text { Acebey, Vigor, Valentin, and } \\
\text { Moulis, } 2009 .\end{array}$ \\
\hline Aquifoliaceae & $\begin{array}{l}\text { Ilex } \\
\text { paraguariensis }\end{array}$ & $\begin{array}{l}\text { antioxidant; antidiabetic; antimicrobial; digestive; skin ulcers; } \\
\text { stimulant; fatigue; vasodilator; ant obesity; mental fatigue; } \\
\text { muscle fatigue; improves appetite; cardiovascular protection; }\end{array}$ & $\begin{array}{l}\text { Lorenzi and Matos, 2008; Gan, } \\
\text { Zhang, Wang, and Corke, } 2018 .\end{array}$ \\
\hline
\end{tabular}




$\begin{array}{lll} & \text { Bromelia } & \text { kidney stones; jaundice; oral wounds; hookworm disease; } \\ \text { Bromeliaceae } & \text { vermifuge; abortive; purgative; antiedema; asthma; bronchitis; } \quad \text { Lorenzi and Matos, } 2008 . \\ & \text { diuretic }\end{array}$

\begin{tabular}{|c|c|c|c|}
\hline \multirow[b]{2}{*}{ Caesalpiniaceae } & $\begin{array}{l}\text { Hymenaea } \\
\text { courbaril }\end{array}$ & bronchitis; asthma; kidney problems; anemia; throat pain; & $\begin{array}{l}\text { Bezerra, Góis, de Brito, de Lima, } \\
\text { Bandeira, Romero, Magalhães, and } \\
\text { Santiago, } 2013 \text {. }\end{array}$ \\
\hline & $\begin{array}{l}\text { Schizolobium } \\
\text { parahyba }\end{array}$ & antiophidic; & $\begin{array}{l}\text { Mendes, Oliveira, Lopes, D. S., } \\
\text { Vale, Alcântara, Izidoro, } \\
\text { Hamaguchi, Homsi-Brandeburgo, } \\
\text { Soares, and Rodrigues, } 2008 .\end{array}$ \\
\hline Cecropiaceae & $\begin{array}{l}\text { Cecropia } \\
\text { glaziovi }\end{array}$ & diuretic; asthma; antihypertensive; cardiotonic; & $\begin{array}{l}\text { Luengas-Caicedo, Braga, Brandão, } \\
\text { and de Oliveira, } 2007 .\end{array}$ \\
\hline Celastraceae & $\begin{array}{l}\text { Maytenus } \\
\text { aquifolia }\end{array}$ & free antiradicals; antioxidant; gastric ulcers; analgesic; & $\begin{array}{l}\text { Niero, Faloni de Andrade, and } \\
\text { Cechinel Filho, } 2011 .\end{array}$ \\
\hline \multirow{3}{*}{ Euphorbiaceae } & $\begin{array}{l}\text { Alchornea } \\
\text { glandulosa }\end{array}$ & immune-mediated inflammation; & $\begin{array}{l}\text { Mascia Lopes, Calvo, Vilegas, and } \\
\text { Carlos, } 2010 .\end{array}$ \\
\hline & $\begin{array}{l}\text { Alchornea } \\
\text { triplinervia }\end{array}$ & gastroduodenal disorders; & $\begin{array}{l}\text { Formagio-Neto, Volobuff,, } \\
\text { Pederiva, Pereira, Sarragiotto, } \\
\text { Cardoso,, Kassuya, and Formagio., } \\
2019 .\end{array}$ \\
\hline & $\begin{array}{l}\text { Sebastiania } \\
\text { klotzschiana }\end{array}$ & antiseptic for wounds; analgesic for caries; warts; & Kott, et al., 1998. \\
\hline Fabaceae & $\begin{array}{l}\text { Erythrina crista- } \\
\text { galli }\end{array}$ & anti-inflammatory; antiseptic for wounds; narcotics; & $\begin{array}{l}\text { Weber, Gorzalczany, Martino, } \\
\text { Acevedo, Sterner, and Anke, } 2005 .\end{array}$ \\
\hline Lauraceae & $\begin{array}{l}\text { Ocotea } \\
\text { odorifera }\end{array}$ & diuretic; anti-rheumatic; repellent; syphilis; sweat; & Lorenzi and Matos, 2008. \\
\hline Melastomataceae & $\begin{array}{l}\text { Leandra } c f . \\
\text { australia }\end{array}$ & antidiabetic; & $\begin{array}{l}\text { Trojan-Rodrigues, Alves, Soares, } \\
\text { and Ritter, } 2012 .\end{array}$ \\
\hline Meliaceae & $\begin{array}{l}\text { Guarea } \\
\text { macrophylla }\end{array}$ & anti-inflammatory; diarrhea; purification; & Correa, 1984. \\
\hline Mimosaceae & $\begin{array}{l}\text { Anadenanthera } \\
\text { colubrina }\end{array}$ & flu; cough; general wounds; diarrhea; anti-inflammatory & $\begin{array}{l}\text { Pedone-Bonfim, Lins, Coelho, } \\
\text { Santana, Silva, and Maia, } 2012 .\end{array}$ \\
\hline \multirow[t]{2}{*}{ Myrtaceae } & $\begin{array}{l}\text { Campomanesia } \\
\text { eugenioides }\end{array}$ & diarrhea; fever; bronchitis; stomach pain; & $\begin{array}{l}\text { Moura-Costa, Nocchi, Ceole, } \\
\text { Mello, Nakamura, Dias Filho, } \\
\text { Temponi, and Ueda-Nakamura } \\
2012 \text {. }\end{array}$ \\
\hline & Eucalyptus spp. & $\begin{array}{l}\text { internal pain; flu; muscle pain; cold; general wounds; fever; } \\
\text { anti-inflammatory; }\end{array}$ & $\begin{array}{l}\text { Vuong, Chalmers, Bhuyan, } \\
\text { Bowyer, and Scarlet, } 2015 .\end{array}$ \\
\hline
\end{tabular}


anti-inflammatory; diarrhea; fever; diuretic; antioxidant;

antimicrobial; bronchitis; digestive; cough; anti-rheumatic;

Eugenia uniflora antihypertensive; vessel relaxing; vermifuge; anxiety; emotional

De Souza, de Oliveira, de Oliveira, problems; gout; hyperlipidemia; hypoglycemia;

Betim, Miguel, and Miguel, 2018.

hypotriglyceridemia; nutrition;

Psidium antiaging; antidiabetic; antimicrobial; antioxidant; anti-

cattleianum inflammatory; cancer;
Pereira, Vinholes, Franzon,

Dalmazo, Vizzotto, and Nora, 2018

Anti-inflammatory; diuretic; antidiabetic; Cancer; Gastric

Piperaceae $\quad$ Piper spp. ulcers; antifungal; repellent; local anesthesia; antibacterial; antiprotozoan; estrogen; against $H$. pylori; women's health;

Durant-Archibold, Santana, and

Gupta., 2018

Ferreira, Costa-Lotufo, Moraes,

Barros, Martins, Cavalheiro,

Bolzani, Santos, and Pessoa 2016. diarrhea; fever; digestive; cold; cough; stomach pain; edema; anti-anemic; cardiotonic; STD; stimulant; fatigue; purgative; ocular disorders; aphrodisiac; arteriosclerosis; asthenia;

Coffea arábica astringent; intestinal pain; body pain; migraine; hypoglycemic; nerve tonic; prolactin producer; rationality; excessive menstrual

Rubiaceae

$$
\text { Psychotria }
$$

carthagenensis

psychoactive;

anti-inflammatory; fever; general wounds; vesicular pain;

Coutarea

gallstones;

hexandra

decandra

skin ulcers; antiophidic; fever; anti-inflammatory;

Salicaceae

Casearia anti-inflammatory; diarrhea; general wounds; cold; antiophidic;

sylvestris gastric ulcers; gastrointestinal problems; flu; leprosy;

bleeding; drowsiness; scorpion poisoning;
Lorenzi and Matos, 2008.; Patay,

Bencsik, and Papp, 2016.

Leal and Elisabetsky, 1996.

Lorenzi and Matos, 2008.

Camponogara, da Silva Brum,

Belke, Faccim de Brum, da Silva

Jesus, Piana, Bauermann, and

Oliveira, 2020.

Ferreira, et al., 2011.

Trevizan, do Nascimento, Santos,

Allophylus $\quad$ tuberculosis; gastrointestinal problems; antioxidant; anti-

Kassuya, Cardoso, Vieira,

edulis inflammatory;

Moreira, Croda, and Formagio,

2016.

Sapindaceae

Matayba anti-inflammatory; antimicrobial; antifungal; antiparasitic; liver elaeagnoides cancer;

Philippi, Duarte, da Silva, de

Souza, Niero, Cechinel-Filho, and

Bueno, 2010 
pseudoquina

\begin{tabular}{|c|c|c|c|}
\hline Tiliaceae & $\begin{array}{l}\text { Luehea } \\
\text { divaricata }\end{array}$ & $\begin{array}{l}\text { cough; cancer; muscle pain; flu; kidney problems; uric acid; } \\
\text { hemorrhoid; sore throat; pneumonia; }\end{array}$ & $\begin{array}{l}\text { Tirloni, Palozi, Schaedler, } \\
\text { Marques, Guarnier, dos Santos, } \\
\text { Lourenço, de Souza, and } \\
\text { Gasparotto Junior, } 2018\end{array}$ \\
\hline
\end{tabular}

\begin{tabular}{|c|c|c|c|}
\hline Urticaceae & Urera baccifera & $\begin{array}{l}\text { prostate hyperplasia; herpes virus } 1 \text { and 2; bladder; urinary } \\
\text { tract; arthritis; edema; gastroduodenal disorders; stomach pain; } \\
\text { anti-rheumatic; cold; analgesic; diarrhea; fever; anti- } \\
\text { inflammatory; }\end{array}$ & $\begin{array}{l}\text { Benvenutti, Dala Vechia, Locateli, } \\
\text { Serpa, Lutinski, Rodrigues Junior, } \\
\text { Corralo, Gutiérrez, Vilegas, } \\
\text { Somensi, Longo, Knihs, da Silva, } \\
\text { de Andrade, and Roman Junior, } \\
2019 .\end{array}$ \\
\hline Verbenaceae & $\begin{array}{l}\text { Vitex } \\
\text { montevidensis }\end{array}$ & skin; diuretic; purification; & $\begin{array}{l}\text { Alice, Vargas, Silva, Siqueira, } \\
\text { Schapoval, Gleye, Henriques, and } \\
\text { Henriques } 1991 .\end{array}$ \\
\hline
\end{tabular}

Fonte: Autores.

The table 1 shows that among the 23 family of species (left column) found on Embu-Verde EPA which members (species) have described a therapeutic use. Mos family have one member with medicinal used, Myrtaceae family being the most cited one (4 citations - Campomanesia eugenioides, Eucalyptus spp., Eugenia uniflora and Psidium cattleianum), followed by the families Anacardiaceae, Euphorbiaceae and Rubiaceae, with 3 citations. Related to the medicinal use, the most cited one was the medicinal anti-inflammatory potential, with 14 plants being indicated for the control of this condition. Other frequently cited conditions are diarrhea, pain, wound treatment, and fever for which there are 8 plants indicated, and diuretic potential for which seven species of Embu-Verde EPA. Moreover, in the table it is evidence that Coffea arábica it the plant with more indication, followed by Ilex paraguariensis, Eugenia uniflora, Piper spp., and Urera baccifera (right column).

Among plants identify on the Embu-Verde EPA and listed as species of interest of the Sistema Único de Saúde (SUS), can be highlighted: Casearia sylvestris Sw., Eugenia uniflora DC, Maytenus aquifolia Mart., E. Schinus terebinthifolius Raddi, popularly known by the names Guaçatonga, Pitanga, Espinheira Santa and Aroeira Pimenteira, respectively.

The species Casearia sylvestris (Flacourtiaceae), also known in Portuguese as bugre branco or café selvagem, is recognized by popular Brazilian medicine for the treatment of diarrhea, colds, and flus when its tree barks are used for preparations. The effect on wounds, leprosy and antiophidic is also acknowledged for its root's preparation. And the leaves are also indicated for the treatment of ulcers and gastrointestinal disorders, and for inflammation (Ferreira, et al., 2011). On the other hand, the infusions and dyes of the leaves and fruits of Pitanga (Eugenia uniflora - of the Myrtaceae family) stand out for their stimulating, fever, anti-enteric, antidiarrheal, anti-hypertensive, anti-rheumatic, and anti-inflammatory properties. The use of this plant is also indicated for the treatment of hyperlipidemia, hypotriglyceridemia, hypoglycemia, bronchitis, coughing, fever, anxiety, diuretic, digestive disorders, worms, gout, vessel relaxing, antioxidant and with antimicrobial properties. In addition, this plant has its nutritional recognition due to the significant amounts of calcium, phosphorus, provitamins A and vitamin C, for this its consumption is recommended (De Souza, et al., 2018). For leaves of the species Maytenus aquifolium (Celastraceae), traditional medicine attributes an antiulcer and analgesic effect. While for the bark of the roots of this plant an antioxidant activity is described (Niero, et al., 2011). Finally, the species Aroeira (Schinus terebinthifolius - of the Anacardiaceae family) is listed as anti-inflammatory, antipyretic, analgesic, and for its purifying properties. Moreover, this specie is recommended to treat sexually transmitted diseases, uterine inflammation, urinary tract infections, skin ulcers and 
gastroduodenal disorders, being available in Brazilian drugstores as phytotherapeutic products, mainly for the maintenance of urogenital health (Carvalho, et al., 2013).

Moreover, the search for plants of Embu-Verde EPA with medicinal potential in the book of Brazilian Medicinal plants and Popular Medicine, published by the creator and founder of the Programa Brasileiro de Saúde - Farmácias Vivas Professor Francisco José de Abreu Matos, points out as medicinal plants the species Coffea arabica L., Ilex paraguariensis A. St.-Hil, Bromelia antiacanta Bertoloni, Coutarea hexandra (Jacq.) K. Schum, and Ocotea odorifera (Vell.) Rohwer (Lorenzi \& Matos, 2008).

Coffee (Coffea arabica - Rubiaceae) is known worldwide for its stimulating potential, increasing rationality, and reducing drowsiness and fatigue due to the presence of caffeine in its seeds, however, popular medicine highlights the hypoglycemic potential. Green and raw seeds present a protective agent against arteriosclerosis, while their toasted seeds are indicated for the treatment of ocular disorders, digestion, cold, migraine (Lorenzi \& Matos, 2008). Patay and colleagues (2016) show that the use of coffee varies among different countries. They point out that in Haiti coffee seeds are used for anemia, edema, and asthenia, in Nicaragua they are used orally for fever and astringent medicine; in Thailand they are used as cardiotonic and nerve tonic; and it is used for the asthma treatment in India. Its leaves are used in Africa to treat diarrhea and intestinal pain in Uganda to treat HIV/AIDS in Cuba for migraine headaches and body pain, headache, and stomach in Nicaragua as a cough suppressor in Peru, for fever and stimulation of prolactin production in Mexico and Liberia as a laxative drug. Also, coffee plant flowers are indicated for the treatment of excessive bleeding during menstruation in Nepal, while their roots are used for scorpion bites in western India; and as aphrodisiac in Ethiopia (Patay, et al., 2016). However, it is important to emphasize that excessive coffee consumption can cause adverse and toxic effects, such as palpitations, insomnia, shivering, vertigo, nervous tension, anxiety, and intoxication. The leaves of the species Ilex paraguariensis, known as erva-mate, which are used as an alternative to coffee consumption in some regions due to its stimulating potential, are also indicated for the treatment of ulcers and wounds, fatigue, appetite improvement, digestion, vessel relaxing effect, antioxidant activity and for muscular and mental fatigue. Gan and colleagues highlight the antimicrobial, antioxidant, ant obesity, antidiabetic potential and cardiovascular protection effects for erva-mate.

For the fruit of $B$. antiacanta (which belongs to Bromeliaceaes family), popularly known as gravatá, a purgative, diuretic, vermifuge and abortive potential is descried. The pulp of its fruit is also indicated for asthma, bronchitis, ancylostomiasis, renal calculi, jaundice, and edema treatment, while their leaves are indicated for cancer sores and oral wounds. The described medicinal potential of the specie of Rubiaceae family, Coutarea hexandra, popularly known as quinabrava, whose peels are indicated for intermittent fevers, malaria, wounds, inflammation, gallstones, and pains in the gallbladder. Finally, the species Ocotea odorifera (from the Lauraceae family), known as canela cheirosa, canela perfumada, sassafras, among others, can use is flowers, narks and made oils of it and is used for sweating, anti-rheumatic, antisiphylitic, diuretic and mosquito repellent (Gan, et al., 2018).

The search for the potential of the other species presents in Embu-Verde EPA species with indication of use in the medicine of plants not mentioned in Renisus or in the book of Lorenzi and Matos allowed the identification of 24 distinct species, which have description of use for the treatment of human pathological conditions in various regions of the world are listed.

For blood system conditions, there are plants described in Embu-Verde EPA as the mentioned Eugenia uniflora, Schinus terebinthifolius, Bromelia antiacanta. The species Justicia carnea Lindl. (Acanthaceae) has its medicinal potential described in popular medicine in Nigeria, where it is known as Ogwu obara which means blood tonic and has therapeutic potential as antianemia due to its properties of blood reinforcement and replacement (Anthonia, Ikechukwu, Uzoma and Sunday, 2019). The species Jatobá (Hymenaea courbaril L. - of the Caesalpiniaceae family) is used by popular Brazilian 
medicine to treat anemia, in addition to being used for renal problems, throat pain, bronchitis and asthma (Bezerra, et al., 2013). According to Luengas-Caicedo and colleagues (2007), the species Embaúba, Cecropia glaziovi Snethlage (Cecropiaceae), is used in Latin America for its anti-hypertensive, cardiotonic, diuretic and anti-asthma potential. For the species Tapiá (Alchornea glandulosa), reports of its potential used for immune-mediated inflammatory diseases (FormagioNeto, et al., 2019). Whereas the species Erythrina crista-galli L. (Fabaceae), known in Brazil as suinãa, is used in popular argentine medicine as anti-inflammatory, narcotic, disinfectant and for wound treatment (Weber, et al., 2005). According to Trojan- Rodrigues e colleagues (2012), the species Leandra cf. australis (Cham.) Cogn is popularly indicated as an antidiabetic agent, although no further studies have been found showing this property. The fruits of aracá, Psidium cattleianum Sabine (Myrtaceae), are also used as antidiabetic, and their antioxidant, anticarcinogenic, antimicrobial, anti-inflammatory and antiaging effects are also highlighted (Pereira, et al., 2018). The species Roubala brasiliensis Klotzsch (Proteaceae), known in brazil as carne de vaca, is indicated for nonspecific and intestinal blood disorders (Violante, Hamerski, Garcez, Batista, Chang, Pott, \& Garcez, 2012). Solanum pseudoquina A. St.-Hil. of the Solanaceaes family, known as coerana, quina-de-São-Paulo, quina-branca, among others, is used to treat fever and malaria (Soares, et al., 2017).

The medicinal use of Embu-Verde EPA plants related to the gastrointestinal system includes species with specific indications and some species with broad indications such as Roupala brasiliensis Klotzsch and the previously mention species: Casearia sylvestris, Eugenia uniflora, Maytenus aquifolium, Coffea arábica, and Ilex paraguariensis. While Tapiá-mirim's teas (Alchornea triplinervia (Spreng.) Müll. Arg. - of the botanical family Euphorbiaceae) are recommended for gastric disorders (Mascia Lopes, et al., 2010). And Moura-Costa and colleagues (2012), indicated the species guabiroba (Campomanesia eugenioides (Camb.) Legrand - Myrtaceae) for diarrhea, stomach pains and fever. On the other hand, the species Lithraea molleoides (Vell.) Engl. is popularly known in Argentina for chichita or molle de Córdoba, and the infusions of its fruits and leaves are used as diuretics and for stomach problems, moreove the decoctions of its branches are indicated for respiratory and digestive diseases, besides being also indicated for arthritis (Kott, et al., 1998). The species of the family Meliaceae, Guarea macrophylla Vahl, is indicated as a purifying, anti-inflammatory agent and for diarrhea (Correa, 1984). And Allophylus edulis Radlk of the Sapindaceae family, known as chal or cocu, is indicated for gastrointestinal disorders, as an anti-inflammatory agent and has anti-Mycobacterium tuberculosis and antioxidant activity (Trevizan, et al., 2016). Also, Luehea divaricata Mart. - Tiliaceae, known as açoita cavalo, which is used in Pantanal to treat kidney diseases, uric acid disorders, sore throat, flu, cough, pneumonia, hemorrhoids, muscle pain and tumors (Tirloni, et al., 2018). The leaves of the plant popularly known as Urtiga brava (Urera bacífera (L.) Gaudich. Ex Wedd., which belongs to the Urticaceae family, has been indicated as anti-rheumatic and anti-inflammatory, and the Peruvian Amerindian group Yanesha uses its licenses for the treatment of stomach disorders, colds with fever, rheumatic pain, arthritis, diarrhea, and stomach pains. While in Brazil they are used in the treatment of bladder diseases, prostate hyperplasia, and urinary tract infection. Studies have indicated antiinflammatory, analgesic, and anti-edematous effects, as well as inhibitory activity against herpes simplex type 1 (HSV-1) and type 2 (HSV-2) (Benvenutti, et al., 2019).

Among plants with indication for the treatment of the nervous system, the species Psychotria carthagenensis Jacq. is Kanesha (Rubiaceae), known in Brazil as casca d'anta, is reported as part of the Ayahuasca hallucinogenic drink, used for religious and social rituals, points to its activity in the central nervous system, but more studies are necessary to ensure its scientific and medical indication (Leal \& Elisabetsky, 1996).

In Embu-Verde EPA there are still plants that can be used for the treatment of wounds and skin-related conditions, such as the already mentioned Erythrina crista-galli L., Coutarea hexandra. Also, and according to Kott (1998) the species Sebastiania klotzschiana (Müll. Arg.) Müll. Arg. (Euphorbiaceae), known in popular argentine medicine as blanquillo or lechero, has external antiseptic potential for wounds in its leaves and branches, while its latex is used for the elimination of 
warts and as analgesic for caries dental use. The species Casearia decandra Jacq., also known in Brazil as guaçatonga, is used by popular medicine as dermatoses healing, anti-inflammatory and antipyretic, and it is still described as antiophidic potential (Camponogara, et al., 2019). Moreover, the plant popularly known as Angico-branco (Anadenanthera colubrina (Vell.) Brenan), which belongs to the Mimosaceae family, is used in popular medicine in northeastern Brazil for the treatment of wounds, but also has indication for diarrhea, cough, bronchitis, flu, inflammation, and wounds (Pedone-Bonfim, et al., 2012). Finally, the species known as tarumã (Vitex montevidensis Cham. of the Verbenaceae family) is indicated as diuretic, depurative and for skin diseases (Alice, et al., 1991).

For the treatment of diseases caused by external pathogens, there are several plants which are indicated, such as Bromelia antiacanta, Coutarea hexandra and Ocotea odorifera, previously mentioned. Moreover, the Tapirira guianensis Aubl (of the Anacardiaceae family), known in Brazil as pau-pombo is also highlighted, once its barks are indicated for the treatment of malaria and diarrhea, while its sap is applied against thrush and e external wounds (Roumy, et al., 2009). The Camboatã (Matayba elaeagnoides Radlk.) that belong to the Sapindaceae family, is popularly used to treat inflammation, analgesia, and liver cancer, besides presenting antinociceptive, antimicrobial, antifungal and antiparasitic activities (Philippi, et al., 2010). Also, there are plants that exhibit anti-ophidic effects such as the one mentioned earlier Casearia decandra Jacq, and the Schizolobium parahyba (Vell) species of the family Caesalpiniaceae, S.F. Blake, popularly known as guapuruvu, whose leaves can be used to neutralize intoxication by snakes (Mendes, et al., 2008). Other plants that have effects against external pathogens and were already mention in here are Allophylus edulis Radl, Psidium cattleianum Sabine.

Even though for many species of the Embu-Verde EPA there are no reports of medicinal use, there are often indication for the families and genera to which they belong. Among them, the eucalyptus (Eucalyptus spp. - of the Myrtaceae family) have not specifically been identified present in Embu-Verde EPA, however the genus has been indicated for the treatment of colds, flus, fever, muscle pain, wounds, internal pains, and inflammations (Vuong, et al., 2015). Additionally, the species of the genus Piper, whose activities reported are antibacterial, antifungal, anti-inflammatory, anti-cancer, antidiabetic, anti-Helicobacter pylori, antiulcer, antiprotozoan, estrogenic, insecticide, local anesthetic, diuretic, and health conditions of the woman's health (Durant-Archibald, et al., 2018). Knowing that most of the medications currently available were inspired or based on natural products, the preservation of species even with no proof or indication for medical use are important for future chemical and pharmacological studies (Newman \& Cragg, 2019).

Based on knowledge of the importance and relevance of the species present in Embu-Verde EPA, it is possible to implement actions that provide the local population with access to this environmental benefit and service. In an AF survey on medicinal species, Miranda (2012) shows that the management and exploitation of medicinal plants occur intensely, since there is a growth in the consumer market. The way plants are extracted does not cause major environmental impacts, because there is no need for deforestation. It is possible to use resources in a rational way, with less impact on the environment and generating economic and social gains, promoting sustainable development, integrated to environmental preservation, on a scientific, ecological, and culturally understandable basis, being fair and balanced, guaranteeing individuals the right to citizenship.

The lack of knowledge about this richness and the potential of native species often leads to a lack of knowledge about its importance. Various actions and projects aim at exploiting the biodiversity of Brazilian environmental resources. However, the lack of awareness limits access to the population to the opportunity to enjoy the entire heritage. The study and dissemination through actions and strategies, which make the population aware of the importance and potential use of the plants present in Embu-Verde EPA can contribute to environmental education and help to recover and promote the sustainable use of these species, awakening the population eyes to the countless possibilities it has (Coradin, 2011).

The National Biodiversity Action and Strategy Plan of Brazil (Ministério do Meio Ambiente, 2017) contains initiatives that incorporate the use of medicinal plants in the SUS, with a view to fostering the foundation of phytotherapy 
production chains. Thus, making available the genetic heritage and traditional knowledge, linked to the production of research and studies that make it possible to include new species in Brazilian pharmacology. All these actions promote the appreciation of traditional knowledge in the use of medicinal plants by society, promoting the improvement of the population living and health conditions. In fact, Sakita, Soares, Kanashiro, Ribas, and Pires, (2016), published a study of the pharmacological potential of the species of the Biosphere green belt, to which Embu-Verde EPA belongs, and highlight the importance of those plants for the municipalities, and for the implementation of actions for preservation and conservation of this ecosystem for present and future generations.

\section{Conclusion}

The importance of environmental resources preservation for current and future generations comprises social, economic, and environmental issues. Therefore, action is needed to make these resources accessible, but, above all, to preserve the environment and its sustainable use. In this context, upon identifying the medicinal potential of the Embu-Verde EPA flora, it was sought to show its importance to the local population and society, based on strategies that foster the need to preserve this natural heritage, based on proposals of a broad, educational scope, identifying the medicinal potential of the EPA flora, expanding the use of space and resources, further disseminating this environmental benefit.

Thus, with the objective of making available the environmental resources of Embu-Verde EPA, from the survey and identification of its medicinal flora, an ecological and social awareness is created, based on education and social mobilization, forming educators with an emphasis on socio-environmental education. It is necessary to know how to preserve, so all actions to promote preservation must be directed to inform and educate, and there must be a harmony between traditional and scientific knowledge in the process of resolving environmental and social issues, highlighting paths leading to the rational use of environmental resources.

Knowledge about biodiversity and the use of medicinal plants present in Embu-Verde EPA considers the principles of traditional treatment in the health area. Several plants present in Embu-Verde EPA have known beneficial effects for the treatment of pathologies and symptoms associated with conditions that affect all the human body systems. Understanding and recognizing the plants medicinal potential is important to promote the strengthening of actions that help both students and the local population to engage in projects that aim at exploring sustainably the environmental benefit present at Embu-Verde EPA.

The medicinal potential of the EPA Embu-Verde flora is still underestimated, it is important the recognition and preservation of the medicinal species by the population; and to carry out future bioprospection studies demonstrating the therapeutic and medicinal potential of other medicinal species of this flora that are still unknown. Although the potential use of medicinal species from Embu-Verde EPA it is evidence, there is still need for future studies to explore the effect of plant on human health. New studies may still discovery and design of new medicines from species of Embu-Verde EPA. More knowledge is required about plants chemical compound and biological characteristic to probe the utility of species to treat pathological conditions and to avoid adverse effects. Furthermore, the publication and dissemination of information about the relevance of Embu-Verde EPA it is yet necessary to improved and aware population.

\section{Acknowledgments}

We are grateful to Anhanguera University of São Paulo, grant number 2019-0325 and Coordination for the Improvement of Higher Education Personnel - CAPES for the financial support.

\section{References}


Alice, C. B., Vargas, V. M. F., Silva, G. A. A. B., Siqueira, N. C. S., Schapoval, E. E. S., Gleye, J., Henriques, J. A. P., \& Henriques, A. T. (1991). Screening of plants used in south Brazilian folk medicine. Journal of Ethnopharmacology. 35 (2), 165-171. doi: 10.1016/0378-8741(91)90069-p

Almeida, F P. (2014). Histórico de criação das categorias de unidades de conservação no Brasil. Dissertação de mestrado, Instituto de Pesquisas Ecológicas, Escola Superior de Conservação ambiental e sustentabilidade, Nazaré Paulista, SP, Brasil.

Anthonia, O. C., Ikechukwu, U. R, Uzoma, N. O., \& Sunday, E. L. U (2019). Nutritive properties of aqueous extract Justicia carnea leaves and its effects on hematological and some biochemical indices of anemia induced male wistar albino rats. Biomedical Research. 30 (4), 18-666. doi: 10.35841/biomedicalresearch.30-18-666

Benvenutti, R. C., Dala Vechia, C. A., Locateli, G., Serpa, P. Z., Lutinski, J. A., Rodrigues Junior, S. A., Corralo, V., Gutiérrez, M. V., Vilegas, W., Somensi, L. B., Longo, B., Knihs, J. F., da Silva, L. M., de Andrade, S. F., \& Roman Junior, W. A. (2019). Gastroprotective activity of hydroalcoholic extract of the leaves of Urera baccifera in rats. Journal of Ethnopharmacology, 250, 112473 doi: 10.1016/j.jep.2019.112473

Bezerra, G. P., Góis, R. W. S., de Brito, T. S., de Lima, F. J. B., Bandeira, M. A. M., Romero, N. R., Magalhães, P. J. C., \& Santiago, G. M. P. (2013). Phytochemical study guided by the myorelaxant activity of the crude extract, fractions and constituent from stem bark of Hymenaea courbaril L. Journal of Ethnopharmacology, 149(1),62-9. doi: 10.1016/j.jep.2013.05.052.

Camponogara, C., da Silva Brum, E., Belke, BV, Faccim de Brum, T., da Silva Jesus, R., Piana, M., Bauermann, L. F, \& Oliveira, S. M. (2019). Casearia decandra leaves present anti-inflammatory efficacy in a skin inflammation model in mice. Journal of Ethnopharmacology, 249, 112436. doi: 10.1016/j.jep.2019.112436

Carvalho, M. G., Melo, A. G. N., Aragão, C. F. S., Raffin, F. N., \& Moura, T. F. A. L. (2013). Schinus terebinthifolius Raddi: chemical composition, biological properties and toxicity. Revista Brasileira de Plantas Medicinais, 15(1), 158-169. Doi: 10.1590/S1516-05722013000100022

Colombo, A. F., \& Joly, C. A. (2010). Brazilian Atlantic Forest lato sensu: The most ancient Brazilian forest, and a biodiversity hotspot, is highly threatened by climate change. Brazilian Journal of Biology, 70 (3), 697-708. doi: 10.1590/S1519-69842010000400002

Coradin, L. (2011). A iniciativa plantas para o futuro. In Coradin, L., Siminski, A., \& Reis, A. Espécies nativas da flora brasileira de valor econômico atual ou potencial: plantas para o futuro - Região Sul. (pp. 25-64). Brasília - DF. Ministério do Meio Ambiente

Correa, M. P. (1984). Dicionário de Plantas Úteis e das Exóticas Cultivadas. 1. Rio de Janeiro: Ministério da Agricultura.

De Souza, A. M., de Oliveira, C. F., de Oliveira, V. B., Betim, F. C. M., Miguel, O. G., \& Miguel, M. D. (2018). Traditional Uses, Phytochemistry, and Antimicrobial Activities of Eugenia Species - A Review. Planta Médica, 84 (17), 1232-1248. doi: 10.1055/a-0656-7262

Dolenc, L. D., Pelosoni, J. C., Fabrinni, M. (2013). APA EMBU-VERDE - Riqueza e Fragilidade num território de conflitos SEAE - Sociedade Ecológica Amigos de Embu. Embu das Artes, SP. Recuperado em 9 de novembro de 2020 de https://seaembu.org/wpcontent/uploads/2020/07/APA_EMBU_VERDE_DEZ_2013.pdf

Durant-Archibold, A. A., Santana, A. I., \& Gupta, M. P. (2018). Ethnomedical uses and pharmacological activities of most prevalent species of genus Piper in Panama: A review. Journal of Ethnopharmacology, 217, 63-82. doi: 10.1016/j.jep.2018.02.008

Embu das Artes (2020). Aspectos históricos, geográficos e Economia. http://www.cidadeembudasartes.sp.gov.br/embu/portal/pagina/ver/209

Ferreira, P. M. P., Costa-Lotufo, L. V., Moraes, M. O., Barros, F. W. A., Martins, A. M. A., Cavalheiro, A. J., Bolzani, V. S., Santos, A. G., \& Pessoa, C. (2011). Folk uses and pharmacological properties of Casearia sylvestris: a medicinal review. Anais da Academia Brasileira de Ciências, 83(4), 1373-1384. doi: $10.1590 / \mathrm{S} 0001-37652011005000040$

Formagio-Neto, F., Volobuff, C. R. F., Pederiva, M. M. C., Pereira, Z. V., Sarragiotto, M. H., Cardoso, C. A. L., Kassuya, C. A. L., \& Formagio, A. S. N (2019). Anti-inflammatory action of an alkaloid, fraction and extract from Alchornea glandulosa in mice. Journal of Ethnopharmacol, 231, 66-72. doi: 10.1016/j.jep.2018.11.001

Gan, R. Y., Zhang, D., Wang, M., \& Corke, H. (2018). Health Benefits of Bioactive Compounds from the Genus Ilex, a Source of Traditional Caffeinated Beverages. Nutrients, 10(11),1682. doi: 10.3390/nu10111682

Kott, V., Barbini, L., Cruañes, M., Muñoz, J. D. D., Vivot, E., Cruañes, J., Martino, V., Ferraro, G., Cavallaro, L., \& Campos, R (1998). Antiviral activity in argentine medicinal plants. Journal of Ethnopharmacology, 64 (1), 79-84. doi: 10.1016/s0378-8741(98)00098-1

Leal, M. B, \& Elisabetsky, E. (1996). Absence of alkaloids in Psychotria carthagenensis Jacq. (Rubiaceae). Journal of Ethnopharmacology, 54 (1), 37-40. doi: $10.1016 / 0378-8741(96) 01448-1$

Lei complementar n 108, de 11 de dezembro de 2008 (2008). Dispõe sobre a criação de unidade de conservação municipal de uso sustentável-área de proteção ambiental APA Embu-Verde. Recuperado em 19 novembro, 2020, de

http://cidadeembudasartes.sp.gov.br/embu/assets/uploads/portal/secre374/Lei_108_-2008.pdf

Lei n 6.902, de 27 de abril de 1981 (1981). Dispõe sobre a criação de Estações Ecológicas; Lei da Área de Proteção Ambiental. Diário Oficial da União. Brasília.

Lorenzi, H. \& Matos, F. J. A. (2008) Plantas Medicinais no Brasil - Nativas e exóticas. (2 ed.) Nova Odessa. Instituto Plantarum.

Luengas-Caicedo, P. E., Braga, F. C., Brandão, G. C., \& de Oliveira, A. B. (2007). Seasonal and Intraspecific Variation of Flavonoids and Proanthocyanidins in Cecropia glaziovi Sneth. Leaves from Native and Cultivated Specimens. Zeitschrift Für Naturforschung C, 62 (9-10):701-9. doi: 10.1515/znc-2007-9-1013

Mascia Lopes, F. C., Calvo, T. R., Vilegas, W., \& Carlos, I. Z. (2010). Anti-inflammatory activity of Alchornea triplinervia ethyl acetate fraction: Inhibition of H2O2, NO and TNF- $\alpha$. Pharmaceutical Biology, 48 (12), 1320-1327. doi: 10.3109/13880201003747463 
Melo, M. A., \& Franco, M. I. (2008). Atlas socioambiental de Embu. Câmara Brasileira do Livro, SP, Brasil. http://www.somapalavraeforma.com.br/wpcontent/uploads/2016/11/atlas_embu.

Mendes, M. M., Oliveira, C. F., Lopes, D. S., Vale, L. H. F., Alcântara, T. M., Izidoro, L. F. M., Hamaguchi, A., Homsi-Brandeburgo, M. I., Soares, A. M., \& Rodrigues, V. M (2008). Anti-snake venom properties of Schizolobium parahyba (Caesalpinoideae) aqueous leaves extract. Phytotherapy research, 22 (7), 859-866.

Ministério do Meio Ambiente (2017). Estratégia e Plano de Ação Nacionais para a Biodiversidade. Recuperado em 9 de novembro de 2020 de https://antigo.mma.gov.br/images/arquivo/80049/EPANB/EPANB_PORT.pdf

Miranda, O. D. E (2012). Levantamento de Espécies Vegetais da Mata Atlântica com Potencial Medicinal. .1-11, 2012. 2020 de https://www.embrapa.br/meio-ambiente/

Mota, M. C. O. (2018). Município de Embu das artes e sua contextualização histórica. Afluente: Revista de Letras e Linguística. 3 (7), 21-45.

Moura-Costa, G, F., Nocchi, S. R., Ceole, L. F., Mello, J. C. P., Nakamura, C. V., Dias Filho, V. P., Temponi, L. G., \& Ueda-Nakamura, T. (2012). Antimicrobial activity of plants used as medicinals on an indigenous reserve in Rio das Cobras, Paraná, and Brazil. Journal of Ethnopharmacology, 143 (2), 631-638. doi: 10.1016/j.jep.2012.07.016

Newman, D. J., \& Cragg, G. M. (2019). Natural Products as Sources of New Drugs over the Nearly Four Decades from 01/1981 to 09/2019. Journal of Natural Products, 83 (3), 770-803. doi: 10.1021/acs.jnatprod.9b01285

Niero, R., Faloni de Andrade, S., \& Cechinel Filho, V. (2011). A Review of the Ethnopharmacology, Phytochemistry and Pharmacology of Plants of the Maytenus Genus. Current Pharmaceutical Design, 17 (18), 1851-1871. doi: 10.2174/138161211796391029

Patay, E. B, Bencsik, T., \& Papp, N. (2016). Phytochemical overview and medicinal importance of Coffea species from the past until now. Asian Pacific Journal of Tropical Medicine, 9(12), 1127-1135. doi: 10.1016/j.apjtm.2016.11.008

Pedone-Bonfim, M. V., Lins, M. A., Coelho, I. R., Santana, A. S., Silva, F. S., \& Maia, L. C. (2012). Mycorrhizal technology and phosphorus in the production of primary and secondary metabolites in cebil (Anadenanthera colubrina (Vell.) Brenan) seedlings. Journal of the Science of Food and Agriculture, 93(6), 1479-84. doi: 10.1002/jsfa.5919

Pereira, E. S., Vinholes, J., Franzon, R. C., Dalmazo, G., Vizzotto, M., \& Nora, L. (2018). Psidium cattleianum fruits: A review on its composition and bioactivity. Food Chemistry, 258, 95-103. doi: 10.1016/j.foodchem.2018.03.024

Philippi, M. E., Duarte, B. M., da Silva, C. V., de Souza, M. T., Niero, R., Cechinel-Filho, V., \& Bueno, E. C. (2010). Immunostimulatory acivity of Calophyllum brasiliense, Ipomoea pes-caprae and Matayba elaeagnoides demonstrated by human peripheral blood mononuclear cells prolipheration. Acta Poloniae Pharmaceutica, 67 (1), 69-73.

Renisus - SUS (2020). Plantas Medicinais de Interesse do SUS - Renisus. https://www.saude.gov.br/acoes-e-programas/programa-nacional-de-plantasmedicinais-e-fitoterapicos/plantas-medicinais-de-interesse-ao-sus-renisus.

Roumy, V., Fabre, N., Portet, B., Bourdy, G., Acebey, L., Vigor, C., Valentin, A., \& Moulis, C. (2009). Four anti-protozoal and anti-bacterial compounds from Tapirira guianensis. Phytochemistry, 70 (2), 305-311. doi: 10.1016/j.phytochem.2008.10.003

Sakita, M. N., Soares, D. M., Kanashiro, M. M., Ribas, D. A., \& Pires, B. C. C. (2018). Biochemical products, natural medicines and pharmaceutical products. Diagnosis of the ecosystem services for provision. In Ecosystem services and human well-being in the São Paulo city green belt biosphere reserve Executive summary. Instituto Florestal, https://www.infraestruturameioambiente.sp.gov.br/institutoflorestal/

Secretaria do Meio Ambiente (2006). Avaliação Integrada de Remanescentes Florestais de Embu. https://www.infraestruturameioambiente.sp.gov.br/institutoflorestal

Soares, V., Bezerra, T. A., Lafetá, R. C. A., Borges, R. M., \& da Silva, A. J. R. (2017). Three New Steroidal Glycoalkaloids from Solanum pseudoquina A. St.-Hil. (Solanaceae). Journal of the Brazilian Chemical Society, 28 (5), 782-789. doi:10.21577/0103-5053.20160229

SOS Mata Atlântica (2020) - Reservas da Biosfera https://www.sosma.org.br/causas/mata-atlantica.

Tirloni, C. A. S., Palozi, R. A. C., Schaedler, M. I., Marques, A. A. M., Guarnier, L. P., dos Santos, G. S., Lourenço, E. L. B., de Souza, L. M., \& Gasparotto Junior, A. (2018). Biomonitoring the cardiorenal effects of Luehea divaricata Mart.: An ethnoguided approach. Journal of Ethnopharmacology, 225, 53-63. doi: $10.1016 /$ j.jep.2018.06.027

Trevizan, L. N. F., do Nascimento, K. F., Santos, J. A., Kassuya, C. A. L., Cardoso, C. A. L., Vieira, M. C., Moreira, F. M. F., Croda, J., \& Formagio, A. S. N. (2016). Anti-inflammatory, antioxidant and anti- Mycobacterium tuberculosis activity of viridiflorol: The major constituent of Allophylus edulis (A. St.-Hil., A. Juss. \& Cambess.) Radlk. Journal of Ethnopharmacology, 192, 510-515. doi: 10.1016/j.jep.2016.08.053

Trojan-Rodrigues, M., Alves, T. L. S, Soares, G. L. G, \& Ritter, M. R. (2012). Plants used as antidiabetics in popular medicine in Rio Grande do Sul, southern Brazil. Journal of Ethnopharmacology, 139 (1), 155-163. doi: 10.1016/j.jep.2011.10.034

Violante, I. M. P., Hamerski, L., Garcez, W. S., Batista, A. L., Chang, M. R., Pott, V. J., \& Garcez, F. R (2012). Antimicrobial activity of some medicinal plants from the cerrado of the central-western region of Brazil. Brazilian Journal of Microbiology, 43 (4), 1302-1308. Doi: 10.1590/S151783822012000400009

Vuong, Q. V., Chalmers, A. C., Bhuyan, D. J., Bowyer, M. C., \& Scarlet, C. J. (2015). Botanical, phytochemical, and anticancer properties of the eucalyptus species. Chemistry and Biodiversity, 12 (6), 907-924. doi: 10.1002/cbdv.201400327

Weber, D., Gorzalczany, S., Martino, V., Acevedo, C., Sterner, O., \& Anke, T. (2005). Metabolites from Endophytes of the Medicinal Plant Erythrina cristagalli. Zeitschrift Für Naturforschung C, 60 (5-6), 467-477. doi: 10.1515/znc-2005-5-616 
Research, Society and Development, v. 10, n. 6, e24810615266, 2021

(CC BY 4.0) | ISSN 2525-3409 | DOI: http://dx.doi.org/10.33448/rsd-v10i6.15266

Yin, R.K. (2015). Estudo de caso. (2 ed.) Porto Alegre: Bookman 